\title{
Wasteland Ecologies: Undomestication and Multispecies Gains on an Anthropocene Dumping Ground
}

\author{
Colin Hoag \\ Filippo Bertoni \\ Aarhus University \\ Nils Bubandt \\ Aarhus University
}

Smith College, choag@smith.edu

Follow this and additional works at: https://scholarworks.smith.edu/ant_facpubs

Part of the Anthropology Commons

\section{Recommended Citation}

Hoag, Colin; Bertoni, Filippo; and Bubandt, Nils, "Wasteland Ecologies: Undomestication and Multispecies Gains on an Anthropocene Dumping Ground" (2018). Anthropology: Faculty Publications, Smith College, Northampton, MA.

https://scholarworks.smith.edu/ant_facpubs/2 


\title{
Wasteland Ecologies: Undomestication and Multispecies Gains on an Anthropocene Dumping Ground
}

Colin Hoag ${ }^{1,2}$, Filippo Bertoni ${ }^{3}$, Nils Bubandt ${ }^{3 *}$

${ }^{1}$ Department of Anthropology, Smith College, Northampton, MA.

${ }^{2}$ Section for Ecoinformatics and Biodiversity, Department of Bioscience, Aarhus University.

${ }^{3}$ Department of Anthropology, Aarhus University, Moesgaard Allé 20, DK-8270 Højbjerg,

Denmark

*Corresponding author: (bubandt@cas.au.dk)

\begin{abstract}
On the western edge of the former brown coal mines in Søby, an area in central Jutland in Denmark that is now protected as a natural and cultural heritage site, a public eyesore hides behind dirt mounds and fences: the waste disposal and recycling facility known as AFLD Fasterholt. Established in the 1970s, when prevailing perceptions were that the entire mining area was a polluted wasteland, the AFLD Fasterholt waste and recycling plant has since changed in response to new EU waste management regulations, as well as the unexpected proliferation of non-human life in the area. Based on field research at this site - an Anthropocene landscape in the heartland of an EU-configured welfare-state - this article is a contribution to the multispecies ethnography and political ecology of wastelands. We argue that "waste" is a co-species, biopolitical happening — a complex symbolic, political, biological, and technological history. We combine ethnographic fieldwork, social history, wildlife observation, and spatial analysis to
\end{abstract}


follow what we call "undomestication," the reconfiguration of human projects by more-thanhuman forms of life into novel assemblies of species, politics, resources, and technologies. Waste landscapes, this article argues, are the result of unheralded multispecies collaboration that can be traced empirically by attending ethnographically to multispecies forms of "gain-making," the ways in which humans and other species leverage difference to find economic and ecological opportunity.

Keywords: multispecies anthropology, waste management, marginal gains, wastelanding

\section{Introduction}

In the discourse on Anthropocene ${ }^{1}$ environments, many have rightly lamented the widespread loss of ecological function and diversity in sites heavily disturbed by humans, portending diminished chances for diverse species survival (Barnosky et al. 2011; Rose 2012; Shine 2010; Steffen et al. 2007; Svenning et al. 2015). How do some species survive in spite of this destruction and environmental decline? In this article, we seek to answer that question by examining wastelands as emergent ecologies of the Anthropocene (Kirksey 2015; see also Fiege 1999). We argue that interspecies collaborations in such environments may be organized in relations of what we call "undomestication." Inspired by new approaches in the social and natural sciences that move beyond the anthropocentrism of conventional ideas about domestication (Haraway 2008; Hare and Woods 2013; Shipman 2011; Scott 2017), we suggest that undomestication describes the process whereby particular elements of human domestication 
are appropriated or undone by non-human species in such a way as to create novel and relatively autonomous relations of human/non-human interdependency.

We suggest that these arrangements of relative interdependency between humans and non-humans are made possible through "marginal gains" that can be traced ethnographically, politically, and ecologically. "Marginal gain" is an analytic developed by Jane Guyer (2004) to describe how people in West Africa generate opportunities for financial gain by creatively exploiting disjunctions between various economic cultures, both local and foreign, non-capitalist and capitalist. We borrow Guyer's (2004) concept to help us understand the sometimes unintentionally productive relations of human exploitation of the non-human world in the Anthropocene. Thus, just as gain-making in a colonial and capitalist world need not be ruled by a single logic (see also Bear et al. 2015), so, too, gain-making in the ruined, multispecies landscapes of the Anthropocene is not circumscribed by the logic of either capital or the occidental anthropos (Kirksey and Helmreich 2010).

The concept of multispecies gain-making seeks to register the ways in which non-human species find ecological room for maneuver in the overdetermined landscapes of human capitalist gain-making (see also Fiege 1999; Wilson 2010). We argue that multispecies marginal gains are "marginal" in the double sense of the term: they are "marginal" in the sense of being small (albeit frequently big enough to carve a niche and a living) and in the sense of often being peripheral to the human and capitalist projects within which they occur.

In this paper, we explore multispecies gain-making in the Anthropocene wasteland of landfill-turned-recycling facility named AFLD Fasterholt in Central Jutland, Denmark. The marginality of the multispecies gain-making we observe at the dumping ground is similar to the marginal kinds of gain that one can observe on the manicured and chemically doused lawns of 
North American suburbia (Robbins 2007). To capture the political ecology of lawn landscapes, Paul Robbins (2007) proposes that we need to cultivate an understanding of "the lawn as autonomous, following its own rules and taking advantage of sociopolitical circumstances even as it is itself taken advantage of by other actors" (2007:13). Robbins' critical political ecology suggests that lawns make people as much as people make lawns. Like Robbins, we are interested in a political ecology that highlights the politics of multispecies gains and historical unintentionality. Waste landscapes, like lawns and other landscapes of the Anthropocene (see also Fiege 1999; Robbins 2012), are full of such politics of undomestication.

Exploring the political ecology of undomestication in the wastelands of the Anthropocene, we are aided also by the emerging cross-disciplinary literature on waste (Gille 2007; Hawkins 2006; Reno 2014, 2015, 2016), in particular the study of "trash animals" and other non-humans who make a living on the landfills and wastelands of capitalism (Nagy and Johnston 2013; Zahara and Hird 2015). In the decades following William Cronon's (1995) famous call to pay scholarly attention to the wildness of urban sidewalks, gardens, dumps, and other instances of "wrong nature," waste has become the focus of much work in the social and environmental sciences. This new critical science literature on waste has drawn attention to the profound heterogeneity of waste, in its meanings, histories, and consequences, going beyond the categorical division and physical elimination of what is discarded or undesired. As much as waste is a human symbolic category, an economic opportunity, and an ecological imperative (Reno 2015:558), it is also a lifeworld in itself (Reno 2014). We follow Joshua Reno (2014) in suggesting that the study of waste needs to focus not merely on the way waste has an impact on and has "significance for" humans and non-humans, but also on how the afterlives of waste, like all modern forms of ruination, are emerging within more-than-human relations of ecology and 
history (see also Hird 2012). Waste is a co-species product, worked upon by munching, decomposing, belching critters as much as by human labor, technology, economy, and imagination.

In this paper, we examine "undomestication" at AFLD Fasterholt between humans on the one hand and red deer (Cervus elaphus), methanogenic microorganisms, and composting microorganisms on the other. Using a variety of methods, we explore three cases studies at AFLD and suggest that all three are examples of undomestication. First, they are multispecies relations that are technologically mediated and epistemologically “opaque." Second, all three cases are characterized by the re-appropriation of some dimension or apparatus of domestication in ways that are driven by human or non-human forms of gain-making but that produce new and unheralded relations of more-than-human sociality.

Our exploration of relations of undomestication in a Central Jutland landscape seeks to complement studies in political ecology that emphasize the irony that even the world's most anthropogenic sites are far less circumscribed by human domination than one might think. Like the lawns studied by Paul Robbins (2007) or the Idaho potato fields studied by Mark Fiege (1999), the minutely managed waste facility at Fasterholt is packed with unheralded non-human agency. We suggest the relationship between human management and non-human agency in this site is not one of control, determination, or domestication in which non-human agency is bent to the will of human management. Nor is it one of non-human opposition or resistance. Rather, the waste facility, its main economic operations, as well as its incidental dimensions, are shot through with human/non-human relations of undomestication - beyond human domestication, control, and, often, awareness. 


\section{The Study Site: Wastelanding the Dump}

In 1979, a municipal dump called "East Depot" (Østdeponi) was established on the western fringe of the former brown coal mining site of Søby (see Figure 1). One of 59 municipal waste disposal sites in Denmark at the time (Miljøministeriet 1983), East Depot received household and industrial waste from six municipalities across Central Jutland, with a human population that today hovers at just over 300,000. The establishment of the site in 1979 (and its extension to include a fly ash disposal area in 1982) marked the zenith of public administrative belief in the value of the area around Søby after decades of degrading by local brown coal industry. Between the late 1930s and the early 1970s, brown coal extraction transformed the formerly flat heath and farmland into a wasteland of parallel rows of sand dunes (tipper) some 30 meters high. People who grew up in the sandy and waterlogged locale, an impoverished and marginal part of the developing welfare state of Denmark, described it as a "lunar landscape" or “an immense sand box.” Søby had become a wasteland. Old washing machines, vacuum cleaners, and other discarded consumer goods can still be found in the landscape of the dump as material traces of this wastelanding.

As Traci Voyles (2015), from whom we borrow the concept of "wastelanding," demonstrates in her study of uranium mining on Navajo land, the cultural project of defining an area as "empty" and "unproductive" is closely entangled with the political and industrial project of exploitation. In Søby, one finds a "sedate" welfare state parallel to the environmental racism of the North American case described by Voyles (2015). In central Jutland, the cultural notion of Søby as a barren, post-industrial landscape paved the way for legislation that cemented its reputation as a wasteland. Polluting industries, such as a metal surface treatment factory, were 
given license to open in the area. A 2009 report of the Ministry of Environment described the thinking at the time:

[T]he deposition of waste in the area was estimated as justifiable, because the ground water and the water in the lakes and streams were already heavily polluted by chemicals following decades of brown coal digging. (Miljøcenter Aarhus 2009:7)

Brown coal also played a secondary role in transforming the Søby area into a wasteland. While brown coal mining practices in the general vicinity of the dump produced a landscape that was symbolically and categorically suited for waste, the unmined brown coal layer and its clay layers beneath the site of the East Depot was ironically deemed to provide a natural, and costeffective, protective liner to prevent seepage of toxins and heavy metals from the dump into the groundwater aquifers that provide drinking water to the surrounding communities. Thus, while brown coal mining brought forward a conceptual wasteland, making it possible to imagine a dump at the site of East Depot, brown coal itself provided a "safe" membrane to keep the dirt of the dump ethically and ecologically contained. This same idea has been described in the ethnographic literature in North American contexts (Reno 2016).

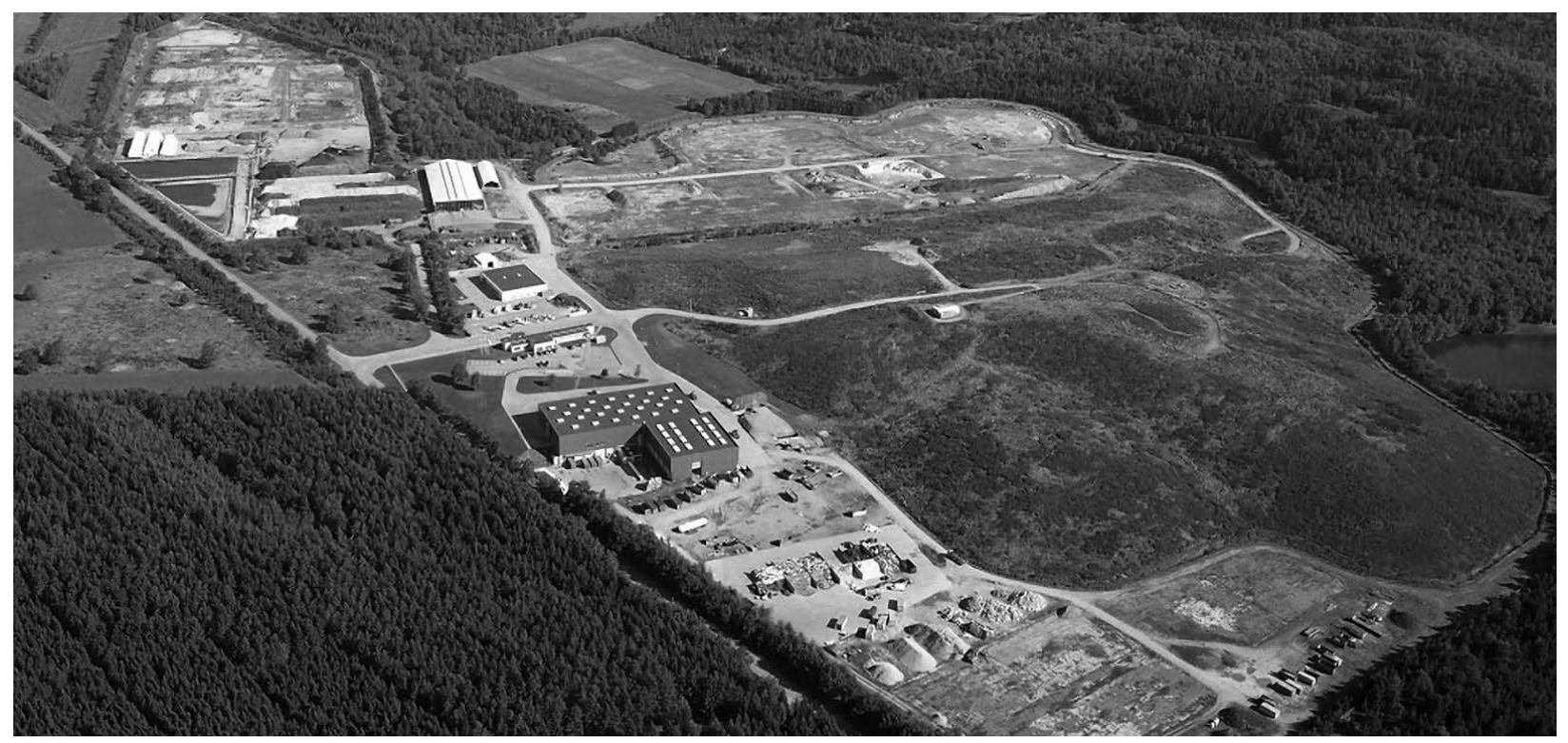

Figure 1: Aerial photo of Østdeponi/AFLD Fasterholt. 
Placing the history of the dump within a broader landscape history reveals something important about wastelands: the specific histories of material-semiotic production in a landscape are critical to understanding how dumps become sites of ethical and environmental exception, where the by-products of modernity can be hidden from view (Gordillo 2014). "Wasting" might be the word to describe this entanglement of wasteland perception and wasteland practices. Categorically a "dirty" and low-status kind of fuel, brown coal helped organize a particular spatio-symbolic order, in which dirt and waste - concepts with a long Judeo-Christian and colonial genealogy (Anderson 1995; Hird and Zahara 2017)—were central (see Douglas 1966). At the same time, brown coal was also the fulcrum for a set of industrial and waste management practices (Reno 2014) that set up the infrastructure and ecologies of this double wasteland: an already polluted area inviting more pollution.

But more was afoot in this landscape of waste than human destruction and environmental exceptionalism. And to see this, we need to turn to its non-humans. For throughout this postmining landscape of the 1970s, mycorrhizal fungal spores began forming symbiotic connections with the roots of lodgepole pines (Pinus contorta), imported from North America and given the name "dune pines" in Danish (klitfyr) for their ability to thrive in the nutrient-poor conditions of sandy environments. As tree cover grew beyond human design and expectation, the lunar landscape gradually morphed into dense but geologically unstable pine forest. With the forests came deer, and with the deer came wolves and hunters.

As a result of the multispecies activities that human disturbance stirred into motion, the Søby area, within a few decades, went from being a barren wasteland to being an undulating landscape of pine forests that, in turn, became the site of a new set of human imaginings; this time municipal dreams of recreation and conservation. In striking contrast to the government 
reports from the 1970s, Søby is today described as "one of the most beautiful and exciting landscapes in the Herning municipality" (Schaldemose 2007), and plans are now in place for a broader requalification of the "East Depot" waste disposal site. This remarkable, largely unintended and unmonitored, transformation from wasteland to "natural" landscape gained legal recognition when in 2007 the former brown coal mining site was declared a protected area, a natural and cultural heritage site (Schaldemose 2007). Now the waste of the past changed status and became an important cultural heritage, collected and displayed at the Brown Coal Museum, located less than a kilometer north of the AFLD waste facility.

At the fringe of this legally reclaimed piece of nature, the East Depot, by the early 2000 s, became an embarrassment. Responding to the new "natural" landscape in which it now found itself, as well as to the intricate architecture of EU regulations and the new economic opportunities for "waste" that this architecture entailed, it was decided to turn East Depot into a "passive disposal site," as part of the gradual process of closing down the site (Miljøcenter Aarhus 2009:7). The former garbage mound, made from organic waste, was covered with soil and was slotted to become a recreational site, a viewing point to the former brown coal area or, in a more ambitious, now abandoned municipal plan, an artificial skiing slope. Søby, one might say, is an example of a post-industrial "brownfield," of which the Anthropocene is replete (Adams et al. 2010), subject to contingent efforts at redefinition by humans in response to productive opportunities partly spurred by the activities of non-humans. In these heterogeneous landscapes, there are marginal gains to be made.

\section{Methods}


We explored three instances of undomestication at the Søby dump: the loose and unheralded relations between red deer worlds and human worlds; the relations between methanogenic microbial metabolisms and humans mediated by the system of pipes at the landfill; and the mediated relations between soil biota and humans at the composting facility at AFLD Fasterholt. We studied these by conducting a series of natural history walks in order to observe and take notes on the landscape; we interviewed nearby landowners who hunt red deer in the areas surrounding AFLD Fasterholt; we interviewed and observed staff of the facility charged with managing waste and the methane it produces; and we made landscape drawingsoften in collaboration with human informants - to map the landscape features of the site.

\section{Undomestication 1: Red Deer Gain-Making}

Walking along the perimeter of this former dump, now a recycling facility, it is hard to miss the paths of red deer (Cervus elephus). Crisscrossing the sandy soils of the waste facility, this well-trafficked network of red deer "highways" is a map of desire-lines that offers clues about the activities and movements of deer in, out of, and across the dumping site (see Figure 2). The red deer tracks leading over the dirt mounds on the western side of the dump, across the site, and through the gaps in the fence and open gates on the northern and eastern side of the dump are also our guides into the multispecies landscape of this waste area. 


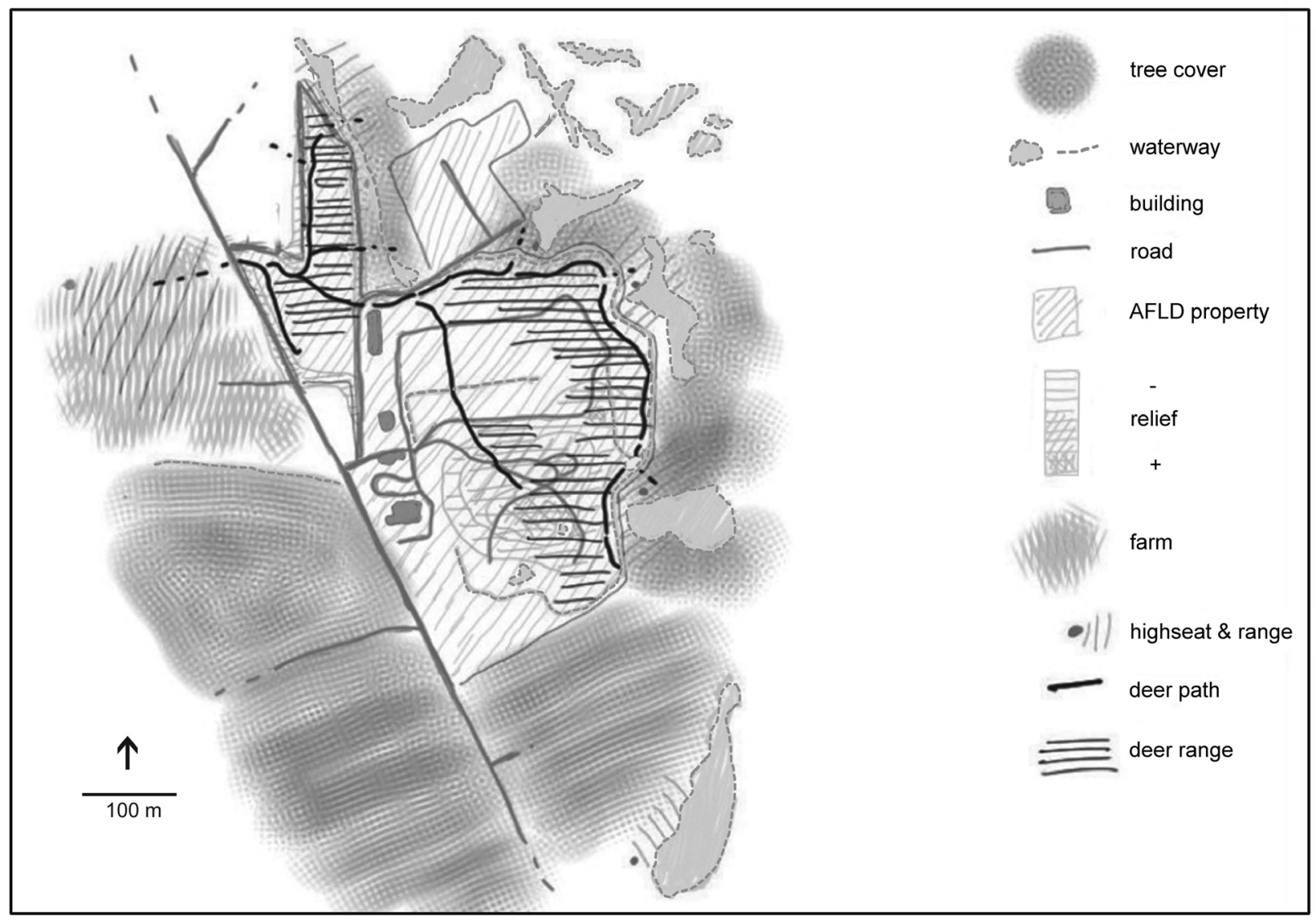

Figure 2: Red deer tracks on and around AFLD Fasterholt. (by Filippo Bertoni)

At first glance, the red deer tracks through AFLD Fasterholt appear to be too complex and random to have a pattern. Yet, when one traces those tracks, as we did during several field research visits in 2016 and 2017, it becomes clear that they are structured by a multispecies ecological and political history. First, the pathways follow the flows of nutrients, water, and pollutants that rain and erosion channel into the topography of the anthropogenic wasteland, yielding configurations of grasses, mushrooms, weeds, shrubs, and trees that make it possible, in some places but not others, for deer to hide, find forage, or socialize. Covering the now abandoned garbage heap at the center of the AFLD Fasterholt property is what municipal documents (Miljøcenter Aarhus 2009) refer to as a "slightly polluted," nitrate-rich layer of 
topsoil. The soil provides habitat for thistles and other nitrate-philic plants that in turn attract fallow deer (Dama dama), roe deer (Capreolus capreolus), and red deer from the adjacent former brown coal mine. In that sense, the pathways are desire-lines to the nitrate-philic vegetation on the former landfill that is unintentionally domesticated — or, as we propose, "undomesticated"-by AFLD management.

Second, the deer pathways are traces of a "landscape of fear" (Brown et al. 1999) involving multiple predators. Attracted by rising red deer populations, grey wolves (Canis lupus) have, in recent years, arrived in Søby and other parts of Jutland from Germany (Steinar 2015), after they had been extirpated from Danish landscapes since 1813. Human hunters, too, contribute to this landscape of fear. Hunters and red deer make landscapes in a cross-species, cross-scale relationship that is highly attuned to an imaginative awareness of the other. Hunters have consequently been quick to notice the red deer preference for moving through the dump area. They have bought up land around the dumping ground and we found they had set up hunting blinds along the perimeter fences on its northern and eastern edges. But, if the red deer remain on the AFLD Fasterholt property, they are relatively safe. Danish law prohibits hunting in industrial and residential areas, so the AFLD Fasterholt waste area is not an active hunting ground, unlike the properties surrounding it.

Just as the legal status of the municipal dump displaces human predators, the noise of its daily activities displaces the generally cautious wolves, allowing the red deer to use it to gain an advantage in the "space race" for territory (Muhly et al. 2011). AFLD employees, some of whom are hunters themselves, share the general view among Danish hunters that red deer are more intelligent than any of the other prey animals and they feel certain that red deer deliberately seek refuge on the ground of the waste facility. Red deer, it would seem, exploit both the legal and the 
ecological heterogeneity of the Søby area, moving between the open pasture on the landfill in the early morning and evening and the closed forest outside it during the day. In that sense, one can see the heavy traffic of red deer inside the dump area, where employees move about discarded materials to be made and unmade as saleable goods largely without regard to deer lifeways, as an anthropogenic form of deer refuge from hunters and wolves.

To what extent this tactic is always entirely successful is an open question, however. In 2014, we found DNA evidence of grey wolf in the saliva taken from the hind leg of a roe deer that we had sampled near the top of the former landfill at AFLD Fasterholt. As thistles seek to make "marginal gains" from the nitrate-rich soils of the former landfill, and deer from the thistles, so, too, wolves seek "marginal gains" from the deer at the dump, even if this puts them within the range of the hunters' rifle scopes.

It is well-established that red deer change behavior in response to changing hunting pressure and different hunting techniques (Jarnemo and Wikenros 2014; Jayakody et al. 2008). Like bears and other mammals, red deer seem to know they are being hunted (Ordiz 2012); their actions are, therefore, also traces of their imaginative awareness of hunters and their world (see also Forssman and Root-Bernstein, this issue). We suggest that the heavy red deer traffic into the dumping ground, in seeming avoidance of active hunting grounds, suggests that red deer know about and respond not merely to the novel presence of wolves and changing hunting practices but also to hunting laws and property borders. The hunting blinds and the permeable fences of the dumping grounds provide the infrastructural link between the legal property lines and hunting territories drawn by a Danish cadastral office and red deer movement. As red deer seek refuge in and passage through the dumping site, they make marginal gains from the differentiated landscape of hunting and dumping. Employees at the dump told us that 
management keeps the gates in the perimeter fence open to allow red deer passage in a deliberate attempt to frustrate surrounding hunters, with whom management has a tense relationship ${ }^{3}$.

This human tension, in dialogue with the landscape of fear, is made into the basis for red deer gain-making. This gain-making happens in relationships of undomestication. The lodgepole pines that today dominate the landscape of the Søby area are "weedy escapees" from forestry experimentation decades earlier. In a similar fashion, the red deer are also escapees from domestication. The "wild" red deer that constitute the symbolically most important big-game hunting trophy in Denmark descend, in part, from the semi-domesticated red deer of fenced royal estates and state forests (Naturstyrelsen 2012). "Weedy" pines and red deer form a relationship of undomestication in the former brown coal site in Søby: their "wild" sociality is a largely unintended, unmonitored, and uncontrolled effect of their histories of domestication.

\section{Undomestication 2: Milking Methane}

Despite having undergone tremendous change over the past century, the AFLD Fasterholt site still allows the visitor to access the landfill's past in the recycling plant. The most evident feature of the facility is the actual landfill — a hill some 50 meters high and today the highest point in this otherwise flat region. In total, about 2.5 million tons of waste lie there, a mixture of organic household waste deposited from 1979 to 1993 and mixed inorganic waste dumped here until 2009. Today, the landfill is covered in grasses, fungi, and thistles that thrive on the nitraterich topsoil covering the landfill. Pipes stick up from the ground-ventilation shafts for the piping that suck up, according to EU regulation, the methane gas produced by the microbial decomposition of waste inside the hill. Every year, the hill slumps several centimeters as the microbial break-down inside of it continues. 
Landfills emit compounds of hundreds of gasses, particularly methane and carbon dioxide, and chiefly through microbial decomposition of organic waste. Methane from garbage heaps is one of the most important sources of anthropogenic methane release to the atmosphere, which is currently almost double that of natural emissions. The Landfill Directive (Council of the European Union 1999/31/EC) and the subsequent Landfill Gas Control Guidance added in 2002 (Council of the European Union 2002) obliges member states to control the accumulation and migration of greenhouse gasses from landfills.

Per, the blacksmith at AFLD Fasterholt, is tasked with complying with EU regulations by overseeing and optimizing the extraction of methane from the depths of the now abandoned landfill ${ }^{4}$. The intricate system of pumps, pipes, and filters that Per has installed in the methane extraction facility is the result of a long series of problems to which Per's tinkering provided solutions and patches. The complex system of 50 vents and some three kilometers of pipes at AFLD Fasterholt landfill, maintained and largely built by Per, originated in the early 1990s but has to be continually optimized to conform to changing EU regulations and to the situation in the dump. The maze of pipes collects the methane and sends it to the nearby town of Arnborg to heat private households, as well as to power the electric facility of Dansk Olie og Naturgas (DONG), the largest energy company in the country.

Per's main worry is water-specifically, how to keep it out of the methane pipes. This problem is growing with time. Methane production - a byproduct of the microbial and fungal decomposition of organic material in the landfill—slowly decreases until it reaches nonprofitable levels after 10-20 years, and eventually ceases entirely after around 100 years. Today, more than three decades since the landfill was established, methane emissions have begun to 
decline and, to keep production levels up, Per needs to increase the vacuum to more than double the industry standard in the underground system of pipes.

Per must continuously devise new and often ingenious ways of keeping the water out as he keeps increasing the vacuum levels. We counted over ten separate contraptions of his creation — all non-industry standards - that keep water out of the piped methane. One of his most ingenious inventions has been to adapt a milking pump to the pipe system. Seeing the dairy technology on a neighboring farm, Per realized that a milking machine's purpose is to separate air from milk and reasoned that the machine could also do the inverse and separate liquid water from methane gas. His repurposing of the milking machine to methane production is an apt example of what we call undomestication. An apparatus from the global complex of cattle domestication, when redeployed in methane production, yields a wilder form of multispecies sociality, characterized less by simplification, intimacy, and control, than by proliferation and haphazard collection.

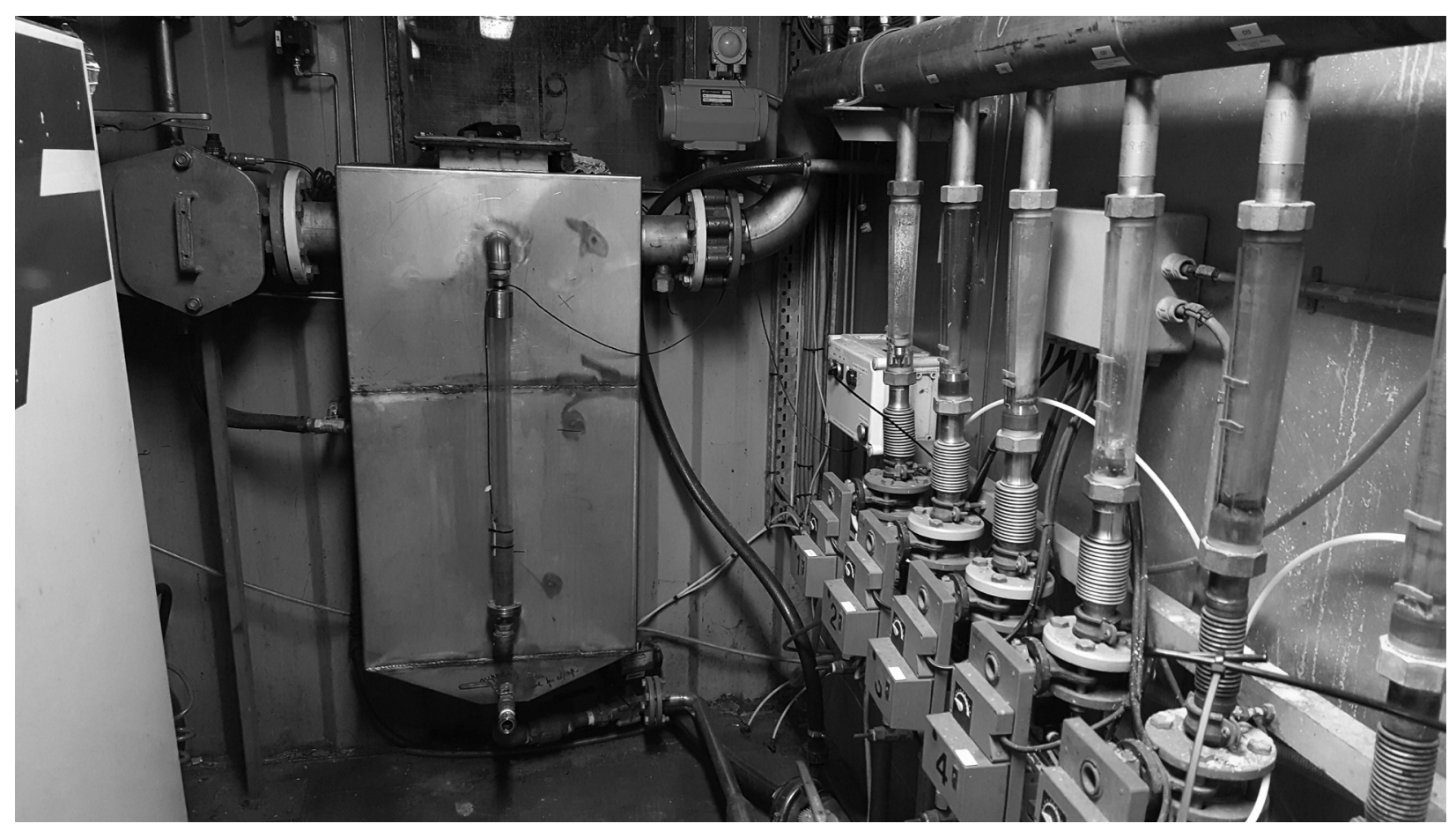




\section{Figure 3: Milking apparatus to separate water and methane. (Photo by authors)}

To make the operation work, Per does not need to know about the archaea and bacteria below that actually emit methane as a byproduct of their metabolism. We suggest that Per's relation to the methanogenic microbial assemblages in the landfill is a loose and unacknowledged, but nevertheless socially important, connection across multispecies worlds. Indeed, when we asked Per where the methane in his pipes came from, his first answer was, "the waste." After some prodding, he said it was "animals in the waste" and, in our third attempt, annoyed at our insistence, he said that it "obviously was bacteria." Per's disinterest in microbial worlds is highly functional. To do his job however, he did not need to care. In this, Per was not alone. Despite the significance of the contribution of methane from landfills to global warming, little is known about the symbiotic relationships between microbial communities involving bacteria, methanogenic archaea, and fungi that are responsible for the complex four-stage conversion of biodegradable waste into methane (hydrolysis, acidogenesis, acetogenesis, and methanogenesis). In fact, molecular studies of microbial assemblages in municipal landfills have recently made tremendous strides thanks to metagenomic techniques (Song et al. 2015), but still must cope with the difficulty of sampling and with the idiosyncratic nature of dumps.

Per's world is not a co-species world with bacteria, fungi, and archaea and his ethnobiological lumping of these microbial critters as "bacteria" makes good functional sense. For Per's world is one of pipes, pumps, gauges, valves, and manifolds, an infrastructure that seeks to harvest the marginal gains on diminishing returns of greenhouse gas, without knowledge of the bacteria that produced it. This system of pipes and valves is connected to and shaped by a political economy in which methane has become a product, a market resource-a political 
economy that operates to a large extent by caring only about the methane and not at all about the microscopic bacteria and archaea that produce it. The makeshift infrastructure and constant tinkering of Per are the result of a concern about gaseous substances (air and methane), a concern that allow Per to convert a greenhouse gas from a toxic pile of garbage into a "green" energy source and a source of wealth. The world of the microorganisms that produce the gas in the landfill below, however, Per does not (and does not need to) care about. Per's relation to this microbial world is a mediated one.

As Brichet and Hastrup (this issue) point out, resources are not discovered; they must be made and invented as part of particular political economies. In the history of Søby, heathland and brown coal were made into "natural resources" at specific historical junctures through modernist forms of tinkering. So, too, Per's infrastructural tinkering turns methane into a resource in Søby which, like the rest of the EU, has entered a dreamy era of "post-waste" in the new millennium, where concerns about environmental destruction and climate change have meant a series of regulations that transform landfill waste from a "bad," best hidden away through a regime of dumping, into an ambivalent "good" and an economic opportunity within an energo-political economy (Alexander and Reno 2014). Undomestication is the condition under which microbes produce methane as a byproduct of their decomposition of the biological components of waste in the pipe-ridden landfill. Undomestication is also the modality under which Per, through an infrastructural maze of pipes and pumps, seeks to ensure the continued extraction of methane as a resource. Per told us that he anticipates being able to extract methane from the landfill for another 4-5 years before his pumps and water-separating manifolds give out. At this point, landfill methane will no longer be a viable resource. But at AFLD Fasterholt, employees 
maintain mediated relations of undomestication to other microbial assemblages in a similar gainmaking project, namely in composting.

\section{Undomestication 3: Composting Waste}

Once a municipal dump, AFLD Fasterholt today is a boutique relay station in a global circulation of waste. The activities and layout of AFLD Fasterholt reflects a new global economy of post-waste. The attempt to deal with waste, the byproduct of capitalist markets, by enrolling it in a market is an ironic instance of capitalist sorcery, whereby capitalism seeks to deal with its problems by re-inscribing them within its own logic (Pignarre and Stengers 2011). AFLD Fasterholt is a cog in the machine of this capitalist logic: a temporary relay station for EUclassified materials that can be plied for marginal gains. For instance, after sorting at AFLD, the non-impregnated wood waste at AFLD Fasterholt is sold to Germany to be pressed into oriented strand boards, while PVC and plastic is compressed into large bales before being sold to China for granulation and resale. Household waste at the sites, meanwhile, is no longer dumped in landfills. Instead, it is sorted and incinerated at the state-of-the-art incineration facility in Esbjerg, a facility that delivers heat to 8,000 households and that was designed in 2003 by the fashionable architectural company Friis \& Moltke.

Waste, one might say, has entered the sphere of "good taste" in Denmark — a radical break with the "dump it and forget it" attitude that drove the establishment of the Søby landfill in 1979. The emergence of waste as a resource also entails a break with the focus on waste incineration that emerged after dumping became problematic. For in the new aesthetic and economy of down-cycling, burning is as "wasteful" as dumping — a problem particularly in Denmark, which produces and incinerates more waste per capita than any other country in the 
EU (Wittrup 2013). Waste incineration, as Alexander and Reno (2014) show, is a contested practice, because it contributes to $\mathrm{CO}_{2}$ emissions and blocks more climate-friendly alternatives, such as bio-mass digesters. Pushed by EU regulations, notably the 2008 EU Waste Framework Directive (Council of the European Union 2008), Denmark has, therefore, in the last few years, embarked on an ambitious plan to prioritize recycling over incineration, both for household and industrial waste. "Denmark Without Waste," as the 2013 master plan is called, aims to recycle and reuse 75 percent of electronics and 25 percent of garden waste from households, as well as 60 percent of organic waste and 70 percent of plastics, glass, metal, and paper from industry by 2022 (Miljøstyrelsen 2013). To manage this shift towards recycling more effectively, an institutional reorganization of waste handling was necessary. The municipalities in charge of East Depot decided to amalgamate it with the waste management facility in Tarm in 2016 . The facility in Tarm, now called "AFLD Tarm," was to continue specializing in paper recycling, while the East Depot—renamed AFLD Fasterholt—would handle plastics and wood composting. AFLD Fasterholt prides itself on its composting skills. The compost facility at the northern end of the site can receive and process over 100 tons of wood from gardens and public parks annually. When one tours the AFLD grounds, as we did on numerous occasions, one walks beside colossal mounds of steaming compost, with bulldozers rumbling by constantly, in their work of tending and turning the piles. Mulch, the end product of the composting process, is sold as soil enrichment to the forestry industry and private garden owners. Decomposition is at the heart of the composting process, just as it is in the landfill to methane process. But the main actors in composting are a different microbial community: aerobic bacteria, fungi, and larger organisms like nematodes and earthworms rather than the mainly anaerobic bacterial and archaeal worlds of landfills (Partanen et al. 2010). Composting by and large involves a three- 
stage process where different assemblages of microorganisms dominate, as temperatures rise and fall (Waksman et al. 1939). Mesophilic bacteria dominate in the initial phase, while thermophilic bacteria and actinobacteria take over as temperatures rise. Finally, in the last phase of the composting process, mesophilic bacteria, fungi, molds, and earthworms complete the mulching process.

The employees and machinery at AFLD work to aid the composting process. Three bulldozers are at work on a daily basis to turn the compost heaps to aerate the compost and transport it to sorting machines that sift the material and separates the fine from the coarser material. The leachate fluids are collected, according to EU regulation, in lined containment ponds for evaporation.

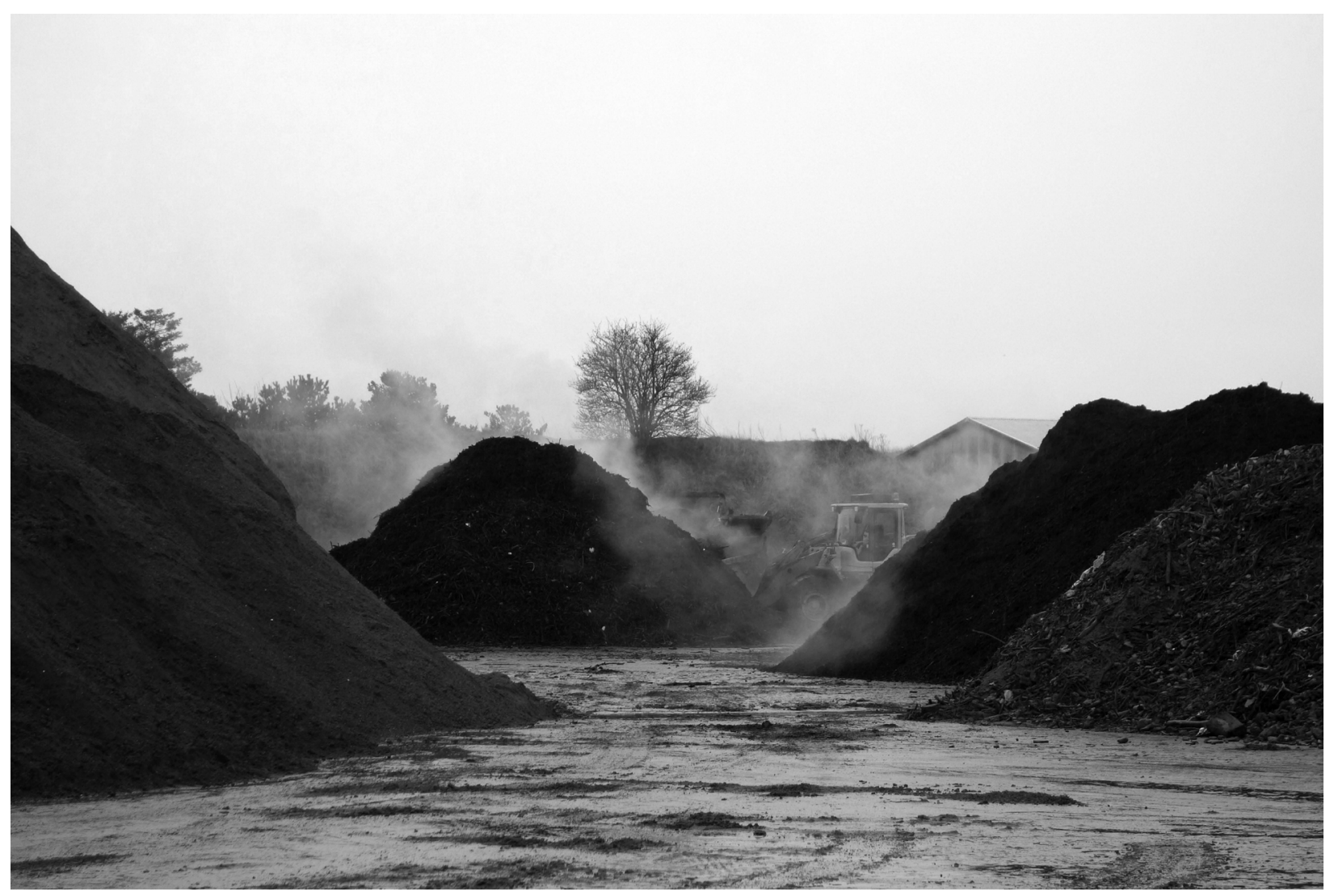

Figure 4: Thermal mist rises from compost heaps at AFLD Fasterholt. (Photo by authors) 
Compost, too, is produced in a relation of undomestication. The mountains of compost give off a constant mist of gasses and heat, as temperatures climb within. According to Morten, one of the employees at the composting site, temperatures can climb up to well above 70 degrees Celsius. The task of Morten and his co-workers is to maintain this high temperature during the second, thermophilic stage of the composting process because the seeds of weeds and the eggs of exotic, Iberian slugs are said to perish at 70 degrees. Weeds and trash animals, such as slugs, are pests in the eyes of private gardeners, who are the intended end-users of the mulch produced. Only a slug-free mulch can become a product. Armed with thermometers at the end of meterlong metal rods, the operators of the bulldozers prod the compost mounds to ascertain when to ventilate them, leveraging bacterial production to exterminate the slugs.

At the end of each cycle, determined by falling temperatures, the material is sifted before being moved to the next stage. The composting site is therefore a landscape of separate mountains of ever-finer, ever cooler, cellulose material. And, like Per at the landfill a few hundred meters away, the composting operators know and care little about the creatures that produce the temperatures as a byproduct of their metabolism, thereby bio-engineering the changing life-world that enables composting. What the pipes and gauges are to Per, the thermometer is to Morten. Composting, like methane milking, makes marginal gains in a relation of undomestication, where human and microbial worlds are mediated by infrastructural system of technologies that allow the microbial lifeworlds to remain largely outside of human knowledge, care, and control.

\section{Discussion: Gain-Making and Undomestication in the Anthropocene}


Our three case studies are different in some ways. While the red deer are incidental to its operations, the bacteria, archaea, and fungi are critical to methane production and composting, among the main economic activities of AFLD Fasterholt. And yet, all these non-human actors are in a relationship of undomestication to the human managers, engineers, and technicians at the site. Unlike the relations of control and close intimacy that are said to govern domestication (Pierotti and Fogg 2017), relations of undomestication are mediated, "extimate," and often promote unheralded forms of multispecies sociality. By "extimacy," a term coined by psychoanalyst Jacques Lacan (1992:139), we mean a relational condition produced through distance and mediation. This contrasts with "intimacy," a condition produced through proximity. Human gain-making from microbial life, for instance, demands constant infrastructural tinkering, but this tinkering entails no direct awareness of, contact with, or control over the microbial world. In the process of methane production at AFLD Fasterholt, human and microbial worlds are linked by extimate relations, as seen in Per's haphazard relationship to those methanogenic microbial assemblages.

Our attempt to trace the importance of "extimate" relations of undomestication between human and non-human worlds mirrors the classic sociological argument that weak ties may sometimes work to bridge otherwise separate tightly-knit social groups of human and, thus, produce important but ignored forms of sociality (Granovetter 1973). Similarly, we suggest that extimate relations of undomestication between human and non-human worlds are critical to the production of anthropogenic landscapes. Human wastelanding practices enable more-thanhuman forms of gain-making that often go unnoticed but nevertheless have a direct and dramatic impact on the landscape: such is the ironic feral metabolism of anthropogenic intervention in numerous sites on a human-shaped planet (Fiege 1999; Gandy 2014; Robbins 2007; Sandberg 
2013). AFLD Fasterholt is for us an exemplar of the many waste-lands of the Anthropocene, in which modern domestication has produced landscapes of ruination and simplification but also multispecies forms of proliferation and undomestication. This allows the site to become an experimental lab in which to explore the ethnographic, historical, and ecological methods that one can apply to study multispecies forms of gain-making and relations of undomestication that characterize and, to a large degree, produce even the most managed landscapes of the Anthropocene. Such is the case at AFLD Fasterholt, an Anthropocene landscape characterized by a combination of the benevolent managerialism of a Northern European welfare state and the banality of an only mildly apocalyptic history of modern disturbance.

Contemporary ecological theory stresses that disturbance is not inherently "bad" and neither does it transform a pure, natural space into a polluted, artificial space (Gunderson 2000). Rather, disturbance constitutes the always-in-the-making world of possibilities and perils to which organisms, including humans, respond. Our ethnographic contribution to a political ecology of disturbed landscapes has been to extend sociological theories about the strength of weak ties to more-than-human worlds in an effort to highlight the need to pay attention to the "extimate" and often cryptic relations between human and non-human worlds. We have demonstrated that such relations of undomestication - the uncoupled associations beyond domestication between humans and non-humans - are critical to emergent ecologies in disturbed landscapes. We suggest that gain-making is a key component of these relations across different worlds, as well as a key object to follow using methods drawn from social and ecological science - as long as by "gain" we understand life-making in a broad, non-human-exceptionalist sense. 
Gain-making and relations of undomestication are historically shaped. We therefore sought to trace how they emerged out of a particular history of wastelanding (Voyles 2015). The brown coal site and the waste management facility are two instances of wastelanding: the former a site of extraction to serve a society addicted to fossil fuel, the latter a site of deposition that receives the waste of the same society. At AFLD Fasterholt, these two waste landscapes are fused by a contingent historical process animated by capitalism, managerialism, and multispecies techno-bio-politics. Marginal gains — economic and ecological — are made by humans and nonhumans in relationships of undomestication by leveraging differences across these worlds. Human law-making, forest management, property rights, pipe-laying, and tinkering may seek to domesticate the multispecies proliferation of this wasteland, but never does so with complete success. Wasteland ecologies are the result of human disturbance, but the life worlds of its multispecies assemblages also exceed it. A double attention to both capitalist and multispecies forms of gain-making under these specific conditions opens up, so we suggest, new avenues for an ethnobiology of the Anthropocene. It highlights that the movement of red deer, the methane emissions of microbial assemblages, and the heat of composting micro- and macroorganisms are not merely effects of ecological livability but also indices of undomestication: multispecies responses to the anthropogenic changes that they also exceed. In the ethnobiology of Anthropocene wastelands, multispecies gain-making and relations of undomestication describe a set of conditions in anthropogenic landscapes under which some organisms succeed and others fail.

\section{Notes}


${ }^{1}$ The concept of the Anthropocene, although relative new and still molten (Swanson et al. 2015), is a strongly contested one, in the natural sciences (Lewis and Maslin 2015; Steffen et al. 2007; Zalasiewicz et al. 2014) as well as in the social sciences (Grusin 2017; Haraway et al. 2016; Palsson et al. 2013; Tsing et al. 2017). We use it here as heuristic device to point to both the discursive sense about — and the ecological reality of — the recent, historically fateful, impact of human, capitalist, and modern projects of expansion on the non-human lifeworlds.

${ }^{2}$ Source: http://afld.dk/anlaeg-fasterholt.aspx

${ }^{3}$ Just how tension-filled, we discovered when camera traps that we set up as part of our study to monitor deer movements through AFLD Fasterholt were stolen.

${ }^{4}$ This section is written in conversation with the description of the same facility by John Law (2016).

\section{Acknowledgments}

We would like to thank Bruno Latour, Isabelle Stengers, John Law, Jens-Christian Svenning, Kenneth Olwig, Bo Fritzbøger, the entire AURA team, as well as the editors and two anonymous reviewers at the Journal of Ethnobiology for helpful comments on earlier drafts. We also would like to thank Pil Birkefeldt Møller Pedersen for helping us track down the DNA test of wolf saliva that was conducted by Liselotte Wesley Andersen. The financial assistance of The Danish National Research Foundation for the research for this article and for AURA as a whole is gratefully acknowledged. 


\section{References Cited}

Adams, D., C. De Sousa, and S. Tiesdell. 2010. Brownfield Development: A Comparison of North American and British Approaches. Urban Studies 47:75-104.

Alexander, Catherine and Joshua O. Reno. 2014. From Biopower to Energopolitics in England's Modern Waste Technology. Anthropological Quarterly 87(2):335-58.

Anderson, W. 1995. Excremental Colonialism. Critical Inquiry 21:640-669.

Barnosky, A. D., N. Matzke, S. Tomiya, G. O. U. Wogan, B. Swartz, T. B. Quental, C. Marshall, J. L. McGuire, E. L. Lindsey, K. C. Maguire, B. Mersey, and E. A. Ferrer. 2011. Has the Earth's Sixth Mass Extinction Already Arrived? Nature 471:51-57.

Bear, L., K. Ho, A. Tsing, and S. Yanagisako. 2015. Gens: A Feminist Manifesto for the Study of Capitalism.” Cultural Anthropology website, Theorizing the Contemporary (March 30 2015). Available at https://culanth.org/fieldsights/652-gens-a-feminist-manifesto-for-thestudy-of-capitalism.

Brown, J.S., J.W. Laundré, and M. Gurung. 1999. The Ecology of Fear: Optimal Foraging, Game Theory, and Trophic Interactions. Journal of Mammalogy 80:385-99.

Council of the European Union. 1999. Council Directive 1999/31/EC of 26 April 1999 on the Landfill of Waste. Available at: http://data.europa.eu/eli/dir/1999/31/oj/eng. Accessed January 28, 2018.

Council of the European Union. 2002. Landfill Gas Control Guidance. Council Directive 1999/31/EC of 26 April 1999 on the Landfill of Waste. Available at: http://ec.europa.eu/environment/waste/landfill/pdf/guidance\%20on\%20landfill\%20gas.pd f. Accessed January 28, 2018. 
Council of the European Union. 2008. Directive 2008/98/EC of the European Parliament and of the Council of 19 November 2008 on Waste and Repealing Certain Directives (Text with EEA Relevance). Available at: http://data.europa.eu/eli/dir/2008/98/oj/eng. Accessed January 28, 2018.

Cronon, W. 1995. The Trouble with Wilderness; Or, Getting Back to the Wrong Nature. In Uncommon Ground. Rethinking the Human Place in Nature. W. Cronon, ed. Pp. 69-90. New York: Norton \& Co.

Douglas, M. 1966. Purity and Danger: An Analysis of Concepts of Pollution and Danger. Routledge, New York, NY.

Fiege, Mark. 1999. Irrigated Eden: The Making of an Agricultural Landscape in the American West. Seattle, WA: University of Washington Press.

Gandy, M. 2014. The Fabric of Space. Water, Modernity, and the Urban Imagination. Cambridge, Mass.: The MIT Press.

Gille, Z. 2007. From the Cult of Waste to the Trash Heap of History: The Politics of Waste in Socialist and Postsocialist Hungary. Bloomington, IN: Indiana University Press.

Gordillo, G. 2014. Rubble. The Afterlife of Destruction. Durham: Duke University Press.

Granovetter, M. 1973. The Strength of Weak Ties. American Journal of Sociology 78:1360-80.

Grusin, R. (ed.). 2017. Anthropocene Feminism. Minnesota: University of Minnesota Press.

Gunderson, L. H. 2000. Ecological Resilience--In Theory and Application. Annual Review of Ecology and Systematics 31:425-39.

Guyer, J. 2004. Marginal Gains: Monetary Transactions in Atlantic Africa. The University of Chicago Press, Chicago, IL.

Haraway, D. 2008. When Species Meet. Minnesota, University of Minnesota Press. 
Haraway, D., N. Ishikawa, S. Gilbert, K. Olwig, A. Tsing, N. Bubandt. 2016. Anthropologists Are Talking - About the Anthropocene. Ethnos 81:535-564.

Hare, B. and V. Woods. 2013. The Genius of Dogs. Discovering the Unique Intelligence of Man's Best Friend. London, Oneworld Publications.

Hawkins, G. 2006. The Ethics of Waste: How We Relate to Rubbish. Rowman \& Littlefield, NY.

Hird, M.J. 2012. Knowing Waste: Towards an Inhuman Epistemology. Social Epistemology 26:453-469.

Hird, M. and A. Zahara. 2017. The Arctic Wastes. In Anthropocene Feminism. Edited by R. Grusin. Pp. 121-146. Minnesota: University of Minnesota Press.

Jarnemo, A. and C. Wikenros. 2014. Movement Pattern of Red Deer during Drive Hunts in Sweden. European Journal of Wildlife Research 60:77-84.

Jayakody, S., A. Sibbald, I. J. Gordon, and X. Lambin. 2008. Red Deer (Cervus elephus) Vigilance Behaviour Differs with Habitat and Type of Human Disturbance. Wildlife Biology 14:81-91.

Kirksey, E. 2015. Emergent Ecologies. Duke University Press, Durham, NC.

Kirksey, E. and S. Helmreich. 2010.The Emergence of Multispecies Ethnography. Cultural Anthropology 25:545-576.

Lacan, J. 1992. The Seminar. Book VII. The Ethics of Psychoanalysis, 1959-60. Trans. Dennis Porter. London: Routledge.

Law, J. 2016. On Pipes and Care. Manuscript available from john.law@open.ac.uk.

Lewis, S., and M. Maslin. 2015. Defining the Anthropocene. Nature 519:171-180.

Miljøministeriet. 1983. Mængde og Sammensætning af Perkolat fra Affaldsdepoter [Volume and Composition of Waste Site Percolation]. August 1983. Copenhagen: Miljø- og 
Fødevarestyrelsen. Available at

http://mst.dk/service/publikationer/publikationsarkiv/1983/jan/maengde-ogsammensaetning-af-perkolat-fra-affaldsdepoter/. Accessed 10 May 2016.

Miljøcenter Aarhus. 2009. Afgørelse om Overgangsplan og revurdering for Affaldsselskabet Østdeponi’s Affaldsbehandlingsanlæg [Decision Regarding Transition Plan and Reassessment for Østdeponi Waste Treatment Plant], Fasterholtgårdvej 10, 7400 Herning. Available at: http://afld.dk/UserFiles/file/Miljogodkendelser/Afgoerelse_om_overgangsplan_og_revud ering_af_18_feb_2009.pdf. Accessed 28 January 2018.

Miljøstyrelsen. 2013. Danmark uden Affald. Genanvend Mere - Forbrænd Mindre [A Denmark Without Waste. Recycle More - Incinerate Less]. Copenhagen: Miljø- og Fødevarestyrelsen. Available at http://mst.dk/virksomhedmyndighed/affald/affaldshaandtering-strategi-aktiviteter/danmark-uden-affald-strategiplan/. Accessed 10 May 2016.

Muhly, T., C. Semeniuk, A. Massolo, L. Hickman, M Musiani. 2011. Human Activity Helps Prey Win the Predator-Prey Space Race. PLoS One 6:e17050.

Nagy, K. and P. D. Johnston (eds.). 2013. Trash Animals: How We Live with Nature's Filthy, Feral, Invasive, and Unwanted. Minneapolis: University of Minnesota Press.

Naturstyrelsen. 2012. Kronvildt i Danmark [Red Deer in Denmark]. Report. Copenhagen, Naturstyrelsen.

Ordiz, A., O. Stoen, S. Saebo, J. Kindberg, M. Delibes, and J. Swenson. 2012. Do bears know they are being hunted? Biological Conservation 152:21-28. 
Palsson, G. Szerszynski, B., S. Sörlin, J. Marks, B. Avril, C. Crumley, H. Hackmann, P. Holm, J. Ingram, A. Kirman, B. Pardo, M. Buendía, and R. Weehuizen. 2013. Reconceptualizing the "Anthropos" in the Anthropocene: Integrating the Social Sciences and Humanities in Global Environmental Change Research. Environmental Science and Policy 28:3-13.

Partanen, P., J. Hultman, L. Paulin, P. Auvinen, and M. Romantschuk. 2010. Bacterial Diversity at Different Stages of the Composting Process. BMC Microbiology 10:94-94.

Pierotti, R. and B. Fogg. 2017. The First Domestication: How Wolves and Humans Coevolved. New Haven: Yale University Press.

Pignarre, P., and I. Stengers. 2011. Capitalist Sorcery. Breaking the Spell. Translated by Andrew Goffey. Palgrave McMillan, Houndsmills.

Reno, J. 2014. Toward a New Theory of Waste: From 'Matter out of Place' to Signs of Life. Theory, Culture, Society 31(6):3-27.

Reno, J. 2015. Waste and Waste Management. Annual Review of Anthropology 44:557-572.

Reno, J. 2016. The Life and Times of Landfills. Journal of Ecological Anthropology 18(1):1-13.

Robbins, P. 2007. Lawn People. How Grasses, Weeds, and Chemicals Make Us Who We Are. Philadelphia: Temple University Press.

Robbins, P. 2012. Political Ecology. A Critical Introduction. Chichester: Wiley-Blackwell.

Rose, D. 2012. Multispecies Knots of Ethical Time. Environmental Philosophy 9:127-140.

Sandberg, A. 2013. The Oak Ridges Moraine Battles: Development, Sprawl, and Nature Conservation in the Toronto Region. Toronto: University of Toronto Press.

Schaldemose, M. 2007. Naturklagenævnets Afgørelse af 29. Maj 2007 om Fredning af Søby Sø og Søby Brunkulslejer i Herning Kommune [Decision by the Nature Review Board of 29 May 2007 on Conservation of Søby Lake and Brown Coal Site in Herning Municipality]. 
Ruling No KKN-111-00012. København: Naturklagenævnet. Available at http://nmkn.dk/media/nmkn/65138/Fredning\%20af\%20Søby\%20Sø\%20og\%20Søby\%20 Brunkulslejer.pdf. Accessed 4 May 2016.

Scott, J. 2017. Against the Grain. A Deep History of the Earliest States. New Haven, Yale University Press.

Shine, R. 2010. The Ecological Impact of Invasive Cane Toads (Bufo Marinus) in Australia. The Quarterly Review of Biology 85:253-291.

Shipman, P. 2011. The Animal Connection: A New Perspective on What Makes Us Human. New York, W. W. Norton

Song, L., Y. Wang, W. Tang, and Y. Lei. 2015. Archaeal Community Diversity in Municipal Waste Landfill Sites. Applied Microbiology and Biotechnology 99:6125-37.

Steffen, W., P. Crutzen, and J. McNeill. 2007. The Anthropocene: Are Humans Now Overwhelming the Great Forces of Nature? Ambio 36:614-621.

Steinar, M. 2015. Ulvene i Danmark [Wolves in Denmark]. www.jaegerforbundet.dk 6/7(2015):22-27.

Svenning, J-C., Pil B. M. Pedersen, C. Josh Donlan, R. Ejrnæs, S. Faurby, M. Galetti, D. Hansen. 2015. "Science for a Wilder Anthropocene: Synthesis and Future Directions for Trophic Rewilding Research.” Proceedings of the National Academy of Sciences, October, 201502556.

Swanson, H., N. Bubandt, and A. Tsing. 2015. Less than One but More than Many: Anthropocene as Science Fiction and Scholarship-in-the-making. Environment and Society: Advances in Research 6:149-166. 
Tsing, A. H. Swanson, E. Gan, and N. Bubandt. 2017. Arts of Living on a Damaged Planet. Ghosts and Monsters of the Anthropocene. Minnesota: University of Minnesota Press. Voyles, T.B. 2015. Wastelanding: Legacies of Uranium Mining in Navajo Country. University of Minnesota Press, Minneapolis, MN.

Waksman, S.A., T.C. Cordon, and N. Hulpoi. 1939. Influence of Temperature upon the Microbiological Population and Decomposition Processes in Composts of Stable Manure. Soil Science 47:83-114.

Wilson, Robert M. 2010. Seeking Refuge: Birds and Landscapes of the Pacific Flyway. Seattle, WA: University of Washington Press.

Wittrup, S. 2013. Danmark er Europamester i Affaldsforbrænding [Denmark Is Leading Incineration in Europe]. Ingeniøren, 22 January 2013 Available at https://ing.dk/artikel/danmark-er-europamester-i-affaldsforbraending-135760. Accessed 25 April 2016.

Zahara, A. and M. Hird. 2015. Raven, Dog, Human: Inhuman Colonialism and Unsettling Cosmologies. Environmental Humanities 7:169-190.

Zalasiewicz, J., C. Waters, M. Williams, A. Barnowski, A. Cearreta, P. Crutzen. 2014. When Did the Anthropocene Begin? A Mid-twentieth Century Boundary Level is Stratospherically Optimal. Quaternary International 383:1-8. 